\title{
PEARL FRANCES GUEST: IN MEMORIAM
}

J. R. JOWSEY, 2635 19th Avenue, Regina, Saskatchewan, S4T 1X2.

When friends and family gathered in Regina at Knox-Metropolitan Church on 15 October in a memorial service to celebrate the life of Pearl Frances Guest, there were representatives present from both the Regina Natural History Society and the Saskatchewan Natural History Society. Members of both organizations will remember Pearl's presence at SNHS summer field meets and on the field trips of the Regina Natural History Society.

Pearl Guest was born in the parkland of eastern Saskatchewan at Theodore in 1902 and died in Regina on October 10, 1980. During her life, she faced courageously such adversities as her stay in the Provincial Sanatorium at Fort Qu'Appelle, and she never lost her appreciation and concern for the natural world. After working as a secretary in various branches of the Saskatchewan Department of Agriculture, she retired on 6 October 1967, and used her leisure to travel about Saskatchewan and other provinces of Canada, and to enjoy her wide associations with family and friends.

Those of us who knew Pearl through her participation in natural history outings will remember her interest in the whole range of birds, mammals and plants, and her generosity in sharing her car and camping equipment with others. She did this with an element of obvious enjoyment of the natural world which Nas unobtrusive but contagious. For larious children, including my own, the presence of Pearl Guest on a field trip made the outing an unusually pleasant experience. On these field trips we had the pleasure of meeting other members of her family too. On field trips and in her other work in her church and community Pearl made a point of including people who were less able, through age or infirmity, to become involved.

Pearl Guest was also involved in the "real work" of the Regina Natural History Society. She served some time on the executive and as secretary and was always willing to give a hand when needed. The twenty-five-year history of the society first mentions Pearl in 1947 when she presented a program. A tew years later she and her brother, John Guest, made a contribution of twelve oak trees for planting in the Hidden Valley Sanctuary in an area which was designated at that time for imported species. In the June 1959 number of the Blue Jay an article by Pearl, "Jeffries Inglewood Bird Sanctuary", is well worth re-reading. She is also mentioned as a participant in the first recorded sighting of a woodcock in the Qu'Appelle Valley (B/ue Jay, December 1960).

Pearl was also a keen observer of the collage of Canadian life and one of her most recent published items of this sort was an article on the transit of the "silk trains" across Canada in the 1920's (Western Producer, August 1979).

Our lives are enriched by the 
variety of persons and experiences we encounter. Pearl Guest's presence among us, her friends, her family, and her working associates, has been memorable experience.

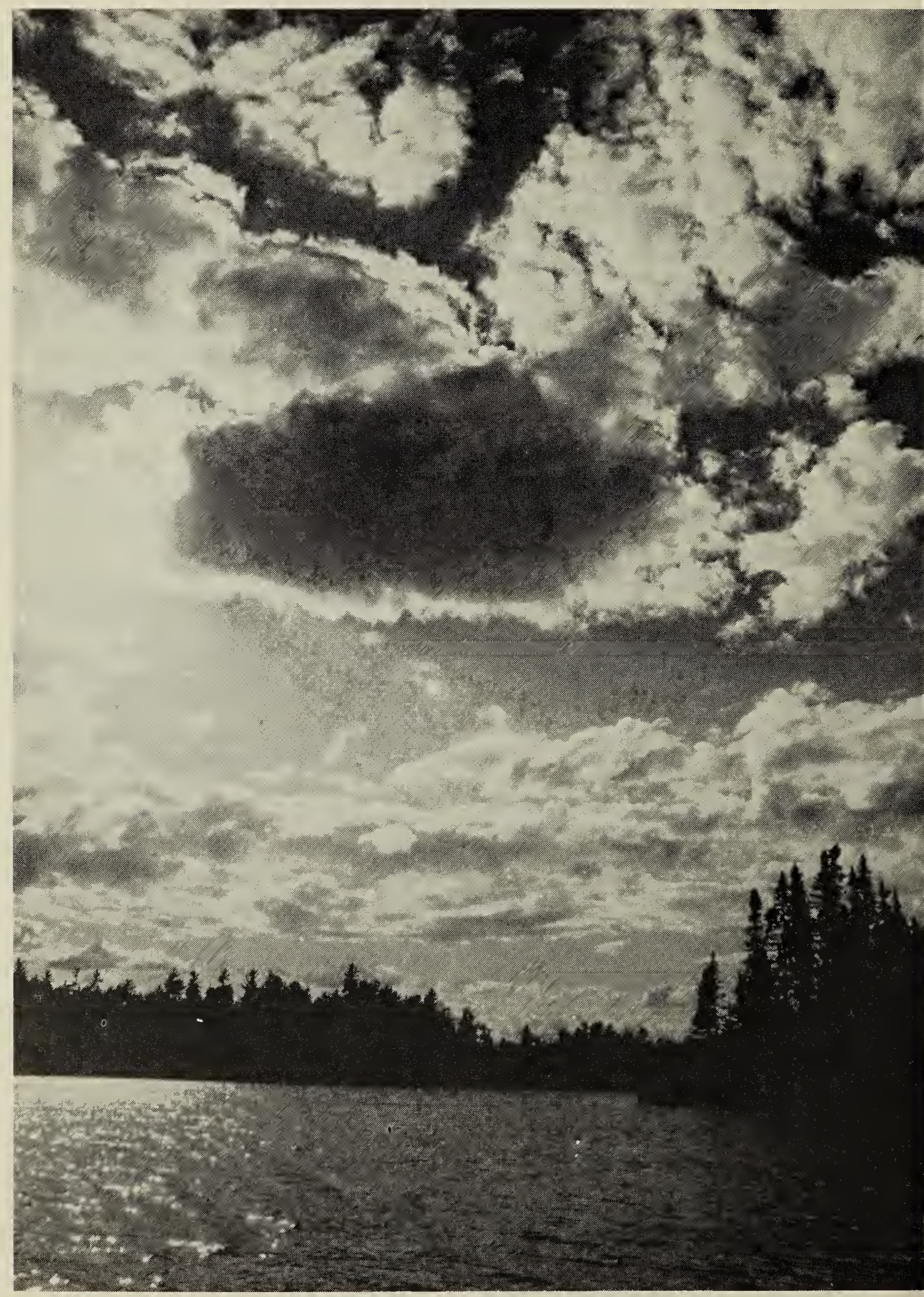

